\title{
Teachers' Views about the Teacher Training Program for Gifted Education
}

\author{
Ayşin Kaplan Say ${ }^{1}$ \\ ${ }^{1}$ Gifted and Talented Education, Bahçeşehir University, İstanbul, Turkey \\ Correspondence: Ayşin Kaplan Sayı, Gifted and Talented Education. Bahçeşehir University, Yıldız mah. Çırağan \\ Cad. Osmanpaşa Mektebi sok. 4-6 34349 Beşiktaş, İstanbul, Turkey.
}

Received: April 10, 2018 Accepted: May 8, 2018 Online Published: May 23, 2018

doi:10.5539/ijel.v8n5p262 URL: https://doi.org/10.5539/ijel.v8n5p262

\begin{abstract}
Gifted children are a special group within the scope of the special education so it is needed to be used by a number of special techniques and teaching methods. However, most teachers do not receive any training about gifted students. This situation-teachers lack of necessary education- can cause gifted students to underachieve or quit the school. The number and variety of professional tranings on gifted students is rather limited. In the study, a teacher training program which aimed to provide teachers experience about the applications on gifted education "Teacher Training Program for Gifted Education" were presented to teachers and teacher views were gathered about the program. Therefore, in order to identify teachers' views on the strengths and limitations of the Teacher Training Program for Gifted Education" constitutes the aim of this study. The research was carried out on 71 teachers in a semi-experimental design on one single group from the experimental models. As data collection tool, a questionnaire consisting of 16 likert type and four quasi-structured in total 20 questions was used developed by the researcher. Accordingly, the participants had a positive opinion with all parts of the training; program, the qualifications of the instructors related to the field, the pedagogical qualifications of the instructors, course progress and testing/assessment. They emphasized the duration of the program and application as the limitiations of the program so they suggest longer duration, branch based training and more applications opportunity.
\end{abstract}

Keywords: gifted children, teacher training on gifted education, teachers' views

\section{Introduction}

Teaching necessitates teachers to be competent in terms of the knowledge about their field, pedagogical and world knowledge. For this reason, it is important that both teacher candidates and teachers have these knowledge and skills and pass them on to practice. Indeed, it is stated that the main problem of teacher education is not applying the knowledge and skills gained in pre-service period (Darling-Hammond \& Bransford, 2005; Hammerness, 2006; Korthagen, 2011).

In order to establish a productive relationships with students, teachers need to have some qualities such as a high level of awareness, the ability to make the learning environment qualified and classroom management skills (Irving \& Martin, 1982). As a matter of fact, teachers should have knowledge of children's learning styles, how they address different individuals, how they evaluate teaching and how to manage a class (Alter \& Coggshall, 2009).

There are many variables in education. The most important variable in the center of all these variables is "teacher." Özcan (2011) emphasizes the importance of the best education for our children and states "the best education is only provided by the best teachers" in the global information society where the knowledge, skills and virtues must be learned to become conscious and productive.

Good education is the right of every child as is the right of gifted children and for presenting this right, having effective teachers is important for them to realize their potential and to be properly oriented. Indeed, an effective teacher can help a gifted child in a few ways. First, s/he identifies the areas in which the child is academically ahead. Secondly, s/he shows the areas where the child weak and develop himself, and works to keep the school as a positive experience for the child. Finally, s/he makes an accurate assessment in order to offer an accelerated teaching for the child. Although popular discourses suggest that gifted children learn by themselves, experts state 
that academically gifted need qualified and knowledgeable teachers (Colangelo, Assouline, \& Gross, 2004).

Although most teachers nowadays realize that the needs of gifted children need to be met, research shows that teachers lack the knowledge, skills and confidence to identify and meet the needs of gifted children. In Adams and Pierce (1994) study which was conducted with prospective teachers and their mentor teachers, he found out that although both groups gave positive responses related to the attitudes and practices in the questionnaire, very few adapted their practice for the needs of different learners in the classroom environment (cited by Adams \& Pierce, 2004). Scientific studies show that teachers' behaviors are positively correlated with level of their knowledge about gifted students (Kiley \& Jensen, 1998; Morris, 1987; Nicely, Small, \& Furman, 1980). This can be interpreted as the teachers' need for a professional help to develop positive attitudes towards gifted children and to reflect this attitude in their classroom practices. Fraser-Seeto, Howard and Woodcock (2015) studied 96 primary school teachers in their research. As a result of the study, all participants indicated that professional development is important to support gifted and talented children. Nevertheless, only $51 \%$ attempted for a professional development related to gifted and talented children. $87 \%$ of those participants stated that they made this effort during in-service training period, $15 \%$ stated that they took it as a compulsory course at undergraduate level and $1 \%$ took it as an elective course in at undergraduate level. When the training The Gifted and Talented Education Kit (DEST/GERRIC) given in 2005 was taken into consideration, it was found that $74 \%$ of the teachers lacked awareness related to this training, $17.7 \%$ heard about the training but did not know what it really was, $5.2 \%$ took part in the training before and $1 \%$ completed it. Although $92.7 \%$ of the participants were willing to receive training on the issue, they stated in their answers to open-ended questions that they did not attend the training because they did not know about it. In the study about 900 state teachers teaching between the 3rd and 12 th grade in the USA, teachers stated that they received very little training about working with academically gifted students. They also indicated that the preparatory programs and the training programs for professional development they participated usually did not include such training. Approximately $65 \%$ of teachers stated that training courses or teacher education programs had little or no focus on academically gifted students. Approximately $34 \%$ of them stated that there is high or medium level of emphasis on this issue. Approximately $58 \%$ of the teachers said that they did not receive any training on teaching to academically gifted students in recent years and $41 \%$ of them stated that they had such training. Yet, the academically gifted benefit more from teachers who receive special training on the topic but very few teachers received such training. For teachers, especially for primary education teachers, to be educated about gifted and talented children is optional rather than necessary. Educators are usually expected to teach these students by leading them to inclusion. According to Gagne's (2008) the Differentiated Model of Giftedness and Talent, "gifted and talented individual" is defined as an individual who has a high potential and is able to show this ability as a performance in one or more fields (mental, creative, and psychomotor) when provided with a suitable environment, offered with strong individual relationships and a pedagogically appropriate education such as enrichment, acceleration and grouping. This potential, strong individual relationships and enrichment, acceleration, grouping and so on. However, gifted and talented children are in both special and general classrooms (Braggett \& Moltzen, 2000; Taylor \& Milton, 2006), so educators need to develop and apply appropriate educational practices for these students in normal classes. Gifted students have a number of different cognitive and social-emotional features such as rapid comprehension of complex information, rapid awareness of relationships, attention to detail, flexible thinking, comprehensive synthesis, in-depth learning and independence, emotionally intense perception, and a high level of self-awareness. Thinking processes become different earlier. As a result, they are early interested in thinking processes such as thinking about probabilities, using abstract terms, drawing conclusions, generalizing, visual thinking, using metaphors and analogies (Clark, 2008). For this reason, gifted children need differentiated, enriched and accelerated education. "Challenging" is the key of an effective training program and to teach for gifted children. Brain research also supports this and suggests that learning occurs only when the brain is adequately stimulated (Caine \& Caine, 1991). This is especially important for gifted children. if the content and tasks remain simple for the gifted child, learning does not occur because gifted child is unable to engage in such as situation. When tasks are not challenging enough, brain cannot secrete dopamine, noradrenalin, serotonin, and other chemicals that are essential for learning (Schultz, Dayan, \& Montague, 1997). In 2001, the Parliament of the Commonwealth of Australia found that $75 \%$ of gifted children were unsuccessful at school and $40 \%$ had left school without completing 12 years. Subsequent studies also reveal the role of educators in the development, learning, participation and success of these students (McCoach, 2007; Plunkett, 2002, \& Rogers, 2007). For this reason, it is important for educators to be sensitive to gifted pedagogy and to know the practices they participate, benefit or reject. This is only possible with teachers who know and understand the needs of gifted students in terms of their educational, social and emotional needs (Hudson, Hudson, Lewis, \& Watters, 2010; Vialle \& Quigley, 2002). This could only be possible with teachers who know the needs of gifted students and understand 
them.

Teacher training for gifted children is not handled as an important paid that is worked on in Turkey. For this reason, studies on the issue are also very limited and insufficient. The undergraduate department, which was originally started as Teacher Training Program for Gifted Students, was combined with all other special fields as Teacher Training Program for Special Education with the sudden decision of HEC in 2016. In Turkey, master level education on the issue is offered by only a total of three universities, one Foundation University and two state universities, whereas doctoral level education is offered by only two state universities. In addition to this, there are certificate programs offered by foundation universities or Turkish MoNE affiliated institutions through payment or as a part of projects. There is also a Training Course for Talented Individuals under the 30-hours Occupational Development Program, which is offered only to state teachers by MoNE. In previous research, findings showed that classroom teachers' knowledge about the subject was rather limited (Gökdere \& Ayvac1, 2004; İnan, Bayındır, \& Demir, 2009). Such training/certification programs are crucial for teachers with such important duties and responsibilities in the process of discovering, educating and directing a gifted child to increase the level of knowledge and skill about the education of gifted individuals. It is thought that this study which demonstrates the effectiveness of such a program, will shed light on in-service training programs on gifted education.

For this reason, the main aim of the present study is to determine teachers' opinions on the strengths and limitations of "Teacher Training Program for Gifted Education" (TTPGE) provided for pre-school, primary school, secondary school and high school teachers about the diagnosis and training of gifted children. Thus, the problem of research is as follows:

What are the views of participants who have been trained in TTPGE?

\section{Method}

This section includes information about research design, study group, data collection tool, analysis of data and application.

\subsection{Research Design}

The present research used quasi-experimental design on one group, which is among the experimental designs. A Likert type questionnaire developed by the researcher was used as the data collection tool. In the study, quantitative data were presented as frequency, mean, standard deviation values; qualitative data were coded and interpreted.

\subsection{Participants}

All participants who were trained in any of certificate programs in Teacher Training Program for Gifted Education; a total of 71 participants during the four semesters were included in the sample.They were asked to complete the "Evaluation of Teacher Training Program for Gifted Education" questionnaire distributed after the certificate program. In Table 1, the distribution of the teachers' genders participating in the certificate programs carried out for each term is presented.

Table 1. The distribution of the teachers participating in certificate programs based on gender

\begin{tabular}{llll}
\hline TTPGE & Female & Male & Total \\
\hline I. Semester & 20 & 3 & 23 \\
II. Semester & 11 & 3 & 14 \\
III. Semester & 5 & 6 & 11 \\
IV. Semester & 20 & 3 & 23 \\
Total & 56 & 15 & 71 \\
\hline
\end{tabular}

As seen in Table 1, 56 of the participants in the study were female and 15 were male.

\subsection{Data Collection Tools}

A questionnaire was prepared by the researcher to measure the perceptions of the participants on the functioning of the TTPGE. The questionnaire consists of 20 items in order to examine the general functioning of the program, the course content and progress, the qualifications of the instructor(s) and their effect on teachers' careers. 16 of these items are rated with a 6-point Likert type scale: I did not get an idea (1), strongly disagree (2), disagree (3), partially agree (4), agree (5), strongly agree (6). In addition, 4 open-ended questions were asked to get more detailed information about the program. 
Table 2. Categories in evaluation questionnaire

\begin{tabular}{lll}
\hline Theme & Categories & Questionnaire Items \\
\hline Program & General perception about the program & $\# 1-\# 4-\# 9$ \\
& Qualifications of instructors related to the field & $\# 3-\# 5-\# 6$ \\
Instructor & Pedagogical qualifications of instructors & $\# 8-\# 13-\# 15-\# 7$ \\
& Course progress & $\# 2-\# 14-\# 5-\# 6-\# 16-\# 11$ \\
Course & Assessment & $\# 10-\# 1-\# 12$ \\
\hline
\end{tabular}

To ensure content validity, similar surveys were searched (Kaul, Johnsen, Witte, \& Saxon, 2015; Lee Olszewski-Kubilius, \& Peternel, 2009) and the questions obtained from the findings were consulted to three professional opinions who were experts on giftedness. Afterwards, 5 participants who participated in the program were distributed the questionnaire to examine and the specific words which were not understood in each question were avoided. For the internal reliability of the questionnaire, the Cronbach's alpha coefficient of all likert types in the questionnaire was examined. In general, the .74 Cronbach alpha (for all 16 questions) coefficient reflects a sufficient level of internal consistency for the questionnaire.

\subsection{Setting}

Teacher Training Program on Gifted Education (TTPGE) was prepared by taking the objectives (Objectives 2.1.1 and 2.1.4) stated in the Turkish Ministry of National Education's 2013-2017 Strategy and Implementation Plan for Gifted Individuals into account (Ministry of National Education [MoNE], 2013). During the program, basic pedagogical formation, thinking-critical thinking and creative thinking training for gifted and talented students and the curriculum integration of these trainings are covered. The aim of the program is to enable teachers to identify gifted children in the classroom, to acquire knowledge about teaching methods and techniques appropriate for gifted and to prepare an enriched and differentiated course content/lesson plan for gifted children. Kindergarten, elementary school and secondary school teachers and teachers who wanted to prepare projects about gifted and talented children and work at resources room equipped for gifted and talented children in their school took part in the program.

The content of the program consists of three stages (gifted students, creative thinking, and critical thinking). At the first stage of the program, the characteristics, needs, education of gifted children and teaching methods and techniques appropriate for gifted children are covered. Steps in thinking and critical thinking at the second level are handled and they are integrated into curriculum. Intelligence games which are very popular in Turkey also covered at the second stage. At the end of the program, creative thinking, the dimensions of creative thinking, creative thinking methods and techniques are studied and their integration into curriculum is also emphasized.

The program was conducted by a university professor who had master's and doctor's degree in the field of gifted children, have been conducting field studies with gifted children for 13 years and had practical experience and an expert who completed undergraduate education in the field of gifted children, had master degree in the field of mentally disabled children and practical experience with both groups. At the beginning of the program, a booklet prepared by the experts was given to the participants considering their possible needs and they were always pre-tested in each practice. The reason for pre-testing participants was to analyze their readiness and needs as learners and to evaluate the effectiveness of the program with the final test.

\subsection{Implementationof the Program}

Saturdays and Sundays, the days when teachers could easily participate in the TTPGE, were selected as training days. For two weeks, the teachers received a total of 40 hours with 10 hours a day, on Saturdays and Sundays. While the training program was being prepared, it was decided that the program would be short-time in order that the teachers coming out of the city could easily reach and the nonattendance would be prevented. The subjects that will be processed each day are given in Table 3 . 
Table 3. Flow chart of TTPGE

\begin{tabular}{l}
\hline Day 1 \\
\hline Definition of Giftedness \\
Physical, Emotional, Social and Personal Characteristics of Gifted Students \\
Differentiation in Gifted Education \\
Instructional Intervention in Gifted Education, Resource Room and Its Scope \\
Gifted Education in Turkey and in the World \\
\hline Day 2 and 3 \\
\hline Definition of Thinking \\
Steps of Thinking Skills \\
Thinking Skills Integration into Curriculum, Definition of Critical Thinking \\
Critical Thinking Skills Integration into Curriculum \\
Integration of Thinking and Critical Thinking Skills for Enriched Educational Practices \\
Examining Sample Practices; Steps in Critical Thinking Integrated into Turkish, Social Studies and Mathematics Curriculum \\
\hline Day 4 \\
\hline Definition of Creative Thinking \\
Definition of Creative Thinking Techniques, Brainstorming Technique and Kinds of Brainstorming \\
SCAMPER Creative Thinking Technique and Application, Sinectics, Creative Thinking Technique and \\
Application, Six Hats Creative Thinking Technique and Application, Creative Problem Solving Technique and Application \\
\hline
\end{tabular}

At the end of the trainings, evaluation questionnaires were distributed to the teachers and a questionnaire was sent by e-mail to the person who could not attend the training that day. While the questionnaires were being filled, practitioners made a small speech to encourage participants and answered possible questions during the survey.

\subsection{Data Analysis}

Descriptive analyses such as frequency, mean and standard deviations were used to show the quantitative data obtained from the questionnaire. Quantitative data obtained from the questionnaire were entered into SPSS software and descriptive statistics were obtained through this software. The Cronbach alpha correlation coefficient was used for the internal validity of the items in the questionnaire. Three-way coding procedure was applied for the analysis of the qualitative data that participants provided. These are open coding, axis coding and selective coding (Strauss \& Corbin, 1990). These coding are often overlapping and parallel, but they differ from each other based on the content. Open coding is considered as the first step of the analysis performed on the data. The aim is to open the basic data and to create the possible categories. Axis coding deals with the linking between the categories that occurred in the previous step. The goal is to place all the data on an axis. Selective coding occurs when the researcher focuses on one of the categories. The goal is to create a whole by linking the analysis that has been done so far (Ilgar \& Ilgar, 2013).

\section{Findings}

In this study the program was evaluated based on themes such as; program, the qualifications of the instructors related to the field, the pedagogical qualifications of the instructors, course progress and testing-assessment. Table 4 shows the results of teachers' evaluation based on these themes.

Table 4. Evaluation results based on themes

\begin{tabular}{llll}
\hline Category & $\mathrm{n}$ & $\mathrm{M}$ & $\mathrm{SD}$ \\
\hline Program & 71 & 5,76 & 0,47 \\
The qualifications of the instructors related to the field & 71 & 5,72 & 0,51 \\
The pedagogical qualifications of the instructors & 71 & 5,82 & 0,53 \\
Course Progress & 71 & 5,60 & 0,65 \\
Testing and Assessment & 71 & 5,66 & 0,57 \\
\hline
\end{tabular}

About the Teacher Training Program for Gifted Education, when the opinions of the teachers regarding the effectiveness of the program are evaluated over 6 points, it is seen that the five areas under evaluation are around and above the score of "5.60".

\subsection{Program}

Three items of the 6-point Likert type were used to obtain an opinion on the program and the consistency of the 
content with the program. According to the results of the survey, participants stated that the content and expectations were clear at the beginning of the program (M: 5.71, SD: 0.51), it had a positive effect on their professional development (M: 5.70, SD: 0.54) and the courses were conducted in line with the program (M: 5.87, SD: 0.33 ). As seen in Table 4, the participants stated that they were generally satisfied with the program (M: 5.76, SD: 0.47).

In responses to answer open-ended questions about the program; the participants $(n=58)$ stated that the program provides enough information about the awareness, recognition, needs, curriculum implementation and guidance of gifted and talented individuals. The participants $(n=42)$ also found the program useful and indicated that it contributed to their personal development as well as their professional and pedagogical development.

The participants noted that the program increased their awareness both generally and of educational program ( $\mathrm{n}$ $=40)$. They stated that the program had sufficient information about the application $(\mathrm{n}=34)$ but nevertheless the program duration had to be extended $(\mathrm{n}=25)$. The program was stated to be satisfying, content-inclusive, encouraging, at a high level of educational attainment and at a level that student were active, all disciplines were addressed, time conformed with content and interdisciplinary communication was enhanced $(n=18)$. However, there are also participants $(n=11)$ who stated that the information on the theoretical and practical part could not be adequately internalized due to lack of time in the program.

Participants also suggested that the program be co-operated with the Ministry of National Education and spread to different student groups and different levels of teaching $(\mathrm{n}=10)$. Apart from the participants who indicated that the information learned in the program was encouraging for further work $(n=14)$, there were also the participants who wanted to have more in-depth knowledge of the program $(n=3)$ and training should be given in a modular form $(\mathrm{n}=3)$.

K2: It met a great deal of my expectations. The education of the gifted and talented children and these features was very uncertain for me. The information was not in place. The content of the given education was presented based on the scientific data and the class discussions. The studies conducted in the field were presented in many dimensions. From these perspectives, I think I have reached more concrete judgments about the subject. It was an important training that would lead future research and studies of mine.

K31: I attended many trainings before but they did not meet my expectations. Since I knew that this course was very useful to me and it met my expectations, I recommended it to all my friends at my school. I thank to the instructors who carried out this training.

K26: It increases consciousness in education. I understand that all methods we know are outdated and useless. I understand that it is not enough to have good subject knowledge. We are information-packed bags. I realized that the methods of transferring these to students are the actual teaching.

\subsection{The Qualification of the Instructors Related to the Field}

Five items of the 6-point Likert type requested to be evaluated as the qualifications of the instructors were directed to the participants. Participants reported in the survey results that the instructors taught the course clearly (M: 5.84, SD: 0.40), were able to use necessary tools and equipment effectively when teaching (M: 5.61, SD: 0.59 ) and could utilize necessary methods and techniques in a way that enables effective participation (M: 5.72, SD: 0.50). As seen in Table 4, the participants stated that the instructors were qualified enough (M: 5.72, SD: 0.51).

Participants generally pointed out in the open-ended questions that they were taught to think differently by the instructors $(n=6)$ and found the instructors useful $(n=8)$. They also indicated that the instructors encouraged the individuals for further work $(\mathrm{n}=14)$.

K7: It was a very good training period. I am very happy to have benefited from the knowledge of our trainers, I had a lot of fun.

K8: Your energy and your desire to teach was very nice, thanks for your effort.

K26: It help me to develop different perspectives, I realized that the preparation process was important and difficult.

K51: It contributed to my professional development. From now on I will try to practice in my own classes.

K62: It gave me an idea of applying high thinking skills into curriculum would be also applied not only for the gifted, even to normal individuals.

K63: I have been given a lot of information and methods that I can practice in the classroom. The training was a 
source of inspiration for many of the activities that I did not have the opportunity to do because of the time limitation.

\subsection{The Pedagogical Qualifications of the Instructors}

Four items of the 6-point Likert type were used for the evaluation of the relationship between the instructors and the participants. According to the results of the questionnaire, participants found their relationship with the instructors to be generally positive (M: 5.82, SD: 0.53). Participants also stated in the questionnaire that the instructors were able to spare time for the participants apart from the classes (M: 5.66, SD: 0.79), the instructors came to class on time and could use time effectively (M: 5.83 SD: 0.53 ), instructors showed positive attitude and behavior (M: 5.91, SD: 0.28) and finally, the speech of the instructors was proper and understandable for themselves (M: 5.88, SD: 0.32).

Participants indicated that the instructors provided sufficient information about the implementation of the program, the theoretical and practical knowledge about the integration of thinking and critical thinking skills, and the increased motivation $(\mathrm{n}=34)$. In addition, the participants stated that the instructors had positive relations with the students $(\mathrm{n}=6)$ and they wanted to maintain communication with the instructors after the program $(\mathrm{n}=7)$.

\subsection{Course Progress}

Two items of the 6-point Likert type were used to measure the perceptions of the participants about the course process and progress. Participants seemed to hold positive attitude towards course process and progress (M: 5.60, SD: 0.65). In addition, it has an effective classroom management (M: 5.90, SD: 0.30), necessary tools and equipment were used effectively during teaching (M: 5.61, SD: 0.59), necessary methods and techniques were used in a way that enables effective participation (M: 5.72, SD: 0.50), the sources used or suggested were related with the course content (M: 5.22, SD: 0.91) and the necessary field/laboratory/practice studies were used at a satisfactory level (M: 5.44, SD: 0.70).

Participants emphasized that they found the course content as theoretically adequate $(\mathrm{n}=26)$, while more practice $(\mathrm{n}=37)$ was needed on the curriculum. They particularly emphasized the need for more time allocated for the steps of thinking skills and creative thinking $(\mathrm{n}=18)$. At the same time, composing curriculum content for different levels of education $(\mathrm{n}=8)$, doing practice with gifted children directly $(\mathrm{n}=6)$, relating the course content to all branches $(n=5)$, video-recording and sharing the practices $(n=5)$ and observation of the participants when teaching to gifted children $(n=3)$ were among the suggestions that the participant made. However, the content of the program was encouraging to practice, sufficient in terms of time $(n=4)$, informing about the updated sources $(n=3)$, and preliminary information of the participants was also actively integrated into the information they newly learned $(\mathrm{n}=3)$.

\subsection{Testing and Assessment}

Participants were given two items of the 6-point Likert type to evaluate the content and the materials given during the courses. Participants stated that testing and assessment applied within the scope of the course was adequate in terms of quality (M: 5.66, SD: 0.57 ). When analyzed based on the items, the participants indicated that the course success was appropriate for the target of the course regarding the methods used for testing (M: 5.78, SD: 0.44), the content and expectations were clear at the beginning of the program (M: 5.71, SD: 0.51) and the instructors provided necessary information about the assignments, examinations and projects to be carried out (M: 5.46, SD: 0.70). Participants were underlined $(n=7)$ that the instructors should spend some time with the students in order to be able to carry out testing and assessment in a healthy way.

K64: It should be emphasized that it is absolutely necessary for the trainees to read the specified before coming to class. Thus, the academic information part can take less time and practice can be given more importance.

K65: As a final step in the program, you can complete the training as an application at the Children's University. For example, we can design a program based on what we have learned. You check it, and if you approve, we practice it with your help at the children's university. If you let everyone have a say, it will be fairer, because when I cannot share the practice I made, I loose my motivation.

K1: The practices might have been more emphasized in the implementation phase and evaluation of different ideas might have been more emphasized in the product creation phase.

\section{Discussion and Conclusion}

One of the important findings from the research is related with the limited parts of the program. The opinion of the teacher in this regard is that "the duration of the training should be kept longer". Similar research results are 
found in related the literature. In their research on science teachers who work with gifted students, Gökdere and Çepni (2004) stated that the teachers pay attention to time and also they empahized that such in service training should be at least 28 hours. In a study on Computer Assisted Language Instruction (CALL) with foreign language teachers, $84 \%$ of the participants found time insufficient $13 \%$ were; found that good and $2 \%$ were unnecessarily long (Hubbar \& Levy, 2006).

When science and arts center's teachers-special centers which present enrichment education for gifted childrenwere asked for their proposal about effective in-service training, the teachers again stressed on the fact that these trainings have to be given by the academicians who have mastered the subject, the time of them should be longer and trainings should be based on practice (Kontaş, 2009). The reason for this, it can be shown that long-term training is more effective for teachers in internalizing the subjects, and long-term training makes the learning more permanent. On the other hand, leaving a long time for the trainings can reduce the attendance and reduce the effectiveness of participation. Because of this most certificate programs are organized around 40 hours. By blending with distance education; it is thought that organizing hybrid trainings can make the time longer and participation more effective.

The second finding in the study is that education should be mainly based on practice. Despite the fact that the given training is almost devoted to practice in three days, the teachers still emphasize that the practice can be more. The reason for this can be shown that the gifted are one of the special education group and the teachers need to study with these students individually. That is they need to get supervision. Again in the study of Kontaş (2009), teachers have underlined the points that there should be implementation of concrete practices as well as theoretical knowledge, there should be an interaction between teachers and trainers and such trainings should be given by more one teaching staff, not by a single person. In the same way, in a study on 'Teachers Preschool Education Inclusive In-service Training Program", it has been seen that most of the weaknesses of the in-service program emphasized the limited time of the program and the necessity of requirements of the intervention methods to be used in practice more than the theoretical knowledge. And they also stressed that when these requirements met, the in-service training programs had been reached the purpose (Özaydın \& Çolak, 2011) In another research, among the reasons of why the teachers do not attend the in service training programmes , Güneş (2006) has indicated that the programmes are not prepared for the needs of teachers and practice is not included enough.

In the in-service training activities, giving emphasis on the practice by taking into account the scope of the training will contribute not to waste the investments and efforts has been made so far also increase the quality of the education service and to make these applications work. However, in this study, the point that the teachers especially identify as "practice and application" is to provide opportunities them to work individually with gifted students. Providing such an opportunity requires a much longer and more cost-effective training progressing as supervision. Supervision can be described as experienced persons (supervisors) prepare the less experienced persons under their supervision and provide support for enriching their practice that can be described as "raising under supervision" (Bradley \& Kottler, 2001). The aim of supervisor is to increase the competence of the supervisee and to develop supervision candidate in the frame of ethical rules by integrating the theoretical knowledge and application experiences (Holloway, 1995). In USA, especially in areas such as Psychological Counseling and Guidance, at least 100 hours are reserved for supervision applications during master and doctoral education (CACREP, 2009; cited by Atik, Arıc1, Ergene, 2014). As it can be seen, supervision is a process in which the supervisee is involved in one-to-one implementation; support of such certification programs by supervision process is within the demands of the teachers. Posnanski (2002), in the research of "Professional Development Program for Primary School Teachers: Analysis of Teacher Self-efficacy and a Professional Development Model", suggest a model for professional development being successful which is long term and based on activities include new teaching method-techniques. In the model it is also emphasized that teachers try teaching techniques in a constructivist / constructivist approach, evaluate themselves and have opportunities to share their views. In this context, it can be said that the certificate programs and in-service trainings organized for the teachers should be designed as long-term, practical and in a way that teachers give feedback to the teachers.

In general, it was observed that participants' attitude about the program, about the functioning of the courses and about the quality of the teachers were positive. For the three selected themes, the mean scores ranged from 5.60 to 5.82 (according to the 6-point Likert-type survey) that they are generally satisfied with the program and that they found the program consistent with the content, that the instructors were qualified and that their involvement with the participants were positive, and finally that the course was well executed and that the content was rich. The reason for this is that the program has been prepared by two special education specialists experienced in the 
field, besides having the experience of teaching; who are also flexible, have strong analytical ability, creative, and have the capacity to differentiate instruction according to participants' needs. As a matter of the fact, for the participants who were more informed than the others; the course was differentiated in terms of speed, resources and the products. As a product participants designed content which high-level thinking skills were integrated to it and at the course this product was differentiated by considering the preferences of the teachers, by giving them flexibility in working subjects and themes which were used during the theoretical lectures. Yüksel and Avc1 (2011) have prepared a curriculum design in which the content, process and product are differentiated by taking into consideration the preliminary learning and information of the students in their work titled "Differentiated Teaching Strategies and Processing of Social Studies Course". According to the results obtained from the interviews made with the students, they said that they enjoyed the learning process, that they learned better, and that it would be better to use the technique in other lessons. In interviews carried with teachers, it is found that teachers do not trust the students at the beginning, that they think students can not understand without teachers presenting but they stated that they have realized the competences of the students in the process so they have to be very well planned as teachers and guide students constantly by walking around the groups and that the students enjoy learning, especially the students who are slow in learning felt very happy. In the same way, Cheng (2006) finds that differentiated English teaching according to the interests, readiness and learning styles of students is more interesting and motivating for students.

In conclusion, the "Teacher Training Program for Gifted Education" (TTPGE) was found productive by the participants; especially the pedagogical qualifications of the instructors, the satisfaction of the program and qualifications of the instructors related to the field. Besides participants underline the duration and practice opportunities. They stated that it is needed more time to carry out such a training and more practicing to work with gifted children effectively. They also reported that they needed individual support and feedback which is mainly the topic of supervision.

\section{Recommendations}

\subsection{Recommedations for Practitioners}

- This type of a training can be designed as hybrid and it will be beneficial to evaluate the results of hybrid training

- Before such trainings are given, it is suggested to provide an environment that allows the participants to spend at least two days with gifted children or to observe them for at least two days.

- Such trainings may be supported by supervisory processes or micro-teaching practices.

\subsection{Recommedations for Researchers}

- Similar studies suggested to be organized in different experimental designs.

- Other studies may be conducted in which teachers' classroom practices participating in this certification program are evaluated.

\section{References}

Adams, C. M., \& Pierce, R. L. (2004). Attitudes of American and English pre-service teachers towards gifted learners. Gifted and Talented International, 19(1), 15-23. https://doi.org/10.1080/15332276.2004.11673028

Alter, J., \& Coggshall, J. G. (2009). Teaching as a clinical practice profession: Implications for teacher preparation and state policy. National Professional Center for Teacher Quality. Washington, DC.

Atik, Z. E., Arıc1, F., \& Ergene, T. (2014). Süpervizyon modelleri ve modellere ilişkin değerlendirmeler. Türk Psikolojik Danışma ve Rehberlik Dergisi, 5(42), 305-317.

Bradley, L. J., \& Kottler, J. A. (2001). Overview of counselor supervision. In L. J. Bradley \& ve N. Ladany (Eds.), Counselor supervision: Principles, process, and practice (3rd ed, pp. 3-27). MI: Taylor \& Francis.

Braggett, E. J., \& Moltzen, R. I. (2000). Programs and practices for identifying and nurturing giftedness and talent in Australian and New Zealand. In K. A. Heller, F. J. Monks, R. J. Sternberg, \& R. F. Subotnik (Eds.), International Handbook of Giftedness and Talent. Oxford, UK: Elsevier.

Caine, R. N., \& Caine, G. (1991). Making connections: Teaching and the human brain. Alexandria, VA: Association for Supervision and Curriculum Development.

Cheng, A. C. (2006). Effect of differentiated curriculum and instruction on Taiwanese EFL students' motivation, anxiety and interest. The Role of English Learning in Taiwan, 128-153. 
Clark, B. (2008). Growing up Gifted (7th ed.) Upper Saddle River, NJ: Prentice.

Colangelo, N., Assouline, S. G., \& Gross, M. U. M. (2004). A nation deceived: How schools hold back America's brightest students. Belin-Blank Centre for Gifted Education and Talent Development. Retrieved January 15, 2018, from https://files.eric.ed.gov/fulltext/ED535137.pdf

Cramond, B., \& Martin, C. E.(1987). Inservice and preservice teachers' attitudes toward academically brilliant. Gifted Child Quarterly, 31, 15-19. https://doi.org/10.1177/001698628703100103

Darling-Hammond, L., \& Bransford, J. (Eds). (2005). Preparing teachers for a changing World: What teachers should learn and be able to do. San Francisco, CA: Jossey-Bass. Retrieved January 20, 2018, from http://books.google.com.tr/books?id=H0uUGKrESDUC\&printsec=frontcover\&hl=tr\&source=gbs_ge_sum mary_r\&cad $=0 \# \mathrm{v}=$ onepage $\& \mathrm{q} \& \mathrm{f}=$ false

Davaslıgil, Ü., \& ve Leana, M. (2004). Üstün Zekâlıların Eğitimi Projesi. I. Türkiye Üstün Yetenekli Çocuklar Kongresi Bildiriler Kitabı. Çocuk Vakfı Yayınları, İstanbul.

Demirkol, M. (2004). İlköğretim okullarında ögretmenlere yönelik okul-temelli hizmet içi eğitim etkinliklerinin değerlendirilmesi (Yayımlanmamış yüksek lisans tezi). Anadolu Üniversitesi Eğitim Bilimleri Enstitüsü, Eskişehir.

Flores, M. A., Santos, P., Fernandes, S., \& Pereira, D. (2014). Pre-service teachers views of their training: Key issues to sustain quality teacher education. Journal of Teacher Education for Sustainability, 16(2), 39-53. https://doi.org/10.2478/jtes-2014-0010

Fraser-Seeto, K. T., Howard, S. J., \& Woodcock, S. (2015). An investigation of teachers' awareness and willingness to engage with a self-directed professional development package on gifted and talented education. Australian Journal of Teacher Education, 40(1), 1-14. https://doi.org/10.14221/ajte.2015v40n1.1

Gadusová, Z., Hasková, A., Malá, E., \& Munková, D. (2013). Technology of education: Terminology in use. Praha: Verbum.

Gagné, F. (2008). Building gifts into talents: Brief overview of the DMGT 2.0. Retrieved February 1, 2018, from http://www.thinkingahead.com.au/Documents/Gagne\%20DMGT\%20Building\%20Gifts\%202008.pdf

Gökdere, M., \& Çepni, S. (2004). Üstün yetenekli öğrencilerin fen öğretmenlerinin hizmet içi ihtiyaçlarının değerlendirilmesine yönelik bir çalışma bilim sanat merkezi örneklemi. Gazi Eğitim Fakültesi Dergisi, 24(2), 1-14.

Gökdere, M., \& ve Ayvacı, H. Ş. (2004). Sınıf öğretmenlerinin üstün yetenekli çocuklar ve özellikleri ile ilgili bilgi seviyelerinin belirlenmesi. On dokuz Mayıs Üniversitesi Eğitim Fakültesi Dergisi, 18, 17-26.

Güneş, M. (2006) Illköğretim okulu öğretmenlerinin hizmet içi eğitim programlarına katılmayı isteme ve istememe nedenleri (Yayınlanmamış yüksek lisans tezi), Hacettepe Üniversitesi Sosyal Bilimler Enstitüsü. Ankara.

Hammerness, K. (2006). From coherence in theory to coherence in practice. Teachers College Record, 108(7), 124-165. https://doi.org/10.1111/j.1467-9620.2006.00692.x

Hanesová, D. (2015). Searching of ways of effective plurilingual teacher trainees preparation. Slavonic Pedagogical Studies Journal: The Scientific Educational Journal, 4(2), 220-240. https://doi.org/10.18355/PG.2015.4.2.220-240

Heritage, M., Kim, J., Vendlinski, T. P., \& Herman, J. L. (2009). From evidence to action: A seamless process in $\begin{array}{llll}\text { formative } \quad \text { assessment? } & \text { Educational 24-31. }\end{array}$ https://doi.org/10.1111/j.1745-3992.2009.00151.x

Holloway, E. L. (1995). Clinical supervision: A systems approach. Ventura, CA: Sage.

Hubbard, P., \& Levy, M. (2006). Teacher Education in CALL. John Benjamins Publishing Company, Philadelphia, USA. https://doi.org/10.1075/11lt.14

Hudson, P., Hudson, S., Lewis, K., \& Watters, J. J. (2010). Embedding gifted education in preservice teacher education: A collaborative school-university approach. Australian Journal of Gifted Education, 19(2), 5-15.

Ilgar, M. Z., \& Ilgar, S. C. (2013). Nitel bir araştırma deseni olarak gömülü teori (Temellendirilmiş Kuram). Retrieved February 5, 2018, from http://www.izu.edu.tr/Assets/Content/File/Enstitu_Sekreterligi/2013_Guz_Donemi_M_Zeki_ilgar_ve_Semr a_Cosgun_ilgar.pdf 
Ilisko, D., Skrinda, A., \& Mieule, I. (2014). Envisioning the future: Bachelor's and master's degree students perspectives. Journal of Teacher Education for Sustainability, 16(2), 88-102. https://doi.org/10.2478/jtes-2014-0013

Irving, O., \& Martin, J. (1982). Withitness: The confusing variable. American Educational Research Journal, 19(2), 313-319. https://doi.org/10.3102/00028312019002313

İnan, H. Z., Bayındır, N., \& ve Demir, S. (2009). Awareness level of teachers about the characteristics of gifted children. Australian Journal of Basic and Applied Sciences, 3(3), 2519-2527.

Kaul, C., Johnsen, S., Witte, M., \& Saxon, T. (2015). Critical components of a summer enrichment program for urban low-income gifted students. Gifted Child Today, 38, 32-40. https://doi.org/10.1177/1076217514556533

Kiley, T. J., \& Jensen, R. A. (1998). What preservice teachers are surprised to learn about ABD from gifted students. Paper presented at tha annual meeting of the American Educational Research Association, San Diego, CA.

Klímová, B. (2015). Assessment in smart learning environment in a case study approach. Smart Innovation, Systems and Technologies, 41. Springer.

Kontaş, H. (2009). Bilsem Öğretmenlerinin Program Geliştirme İhtiyaçlarına Illişkin Geliştirilen Programın Etkililiği. Yayınlanmamış Doktora Tezi, Hacettepe Üniversitesi Sosyal Bilimler Enstitüsü.

Korthagen, F. A. J. (2011). Making teacher education relevant for practice: The pedagogy of realistic teacher education. Orbis Scholae, 5(2), 31-50. https://doi.org/10.14712/23363177.2018.99

Lee, S., Olszewski-Kubilius, P., \& Peternel, G. (2009). Follow-up with students after 6 years of participation in Project EXCITE. Gifted Child Quarterly, 53, 137-156. https://doi.org/10.1177/0016986208330562

McCoach, D. B. (2007). What predicts teachers' attitudes toward the gifted? Gifted Child Quarterly, 51(3), 246-255. https://doi.org/10.1177/0016986207302719

Milli Eğitim Bakanlığı. (2013). Özel yetenekli bireyler strateji ve uygulama planı 2013-2017. Retrieved from https://abdigm.meb.gov.tr/projeler/ois/005.pdf

Mills, J. C. (2003). Characteristics of effective teachers of gifted students: teacher background and personality styles of students. Gifted Child Qurterly, 47(4), 272-281. https://doi.org/10.1177/001698620304700404

Morris, S. K. (1987). Student teachers' attitudes toward gifted students. Creative Child and Adult Quarterly 12, 112-114.

Nicely, Jr., R., Small, J., \& Furman, R. (1980). Teachers' attitudes toward gifted children and program; Implications for instructional leadership. Education, 101, 12-15.

Ozcan, D., \& Kotek, A. (2014). What do the teachers think about gifted students? 2nd Global Conference on Psychology Researches. Proceedings of the Social and Behavioral Sciences, 190, 569-573. https://doi.org/10.1016/j.sbspro.2015.05.044

Özaydın, L., \& Çolak, A. (2011). Okul öncesi öğretmenlerinin kaynaştırma eğitimine ve okul öncesi eğitimde kaynaştırma eğitimi hizmet içi eğitim programına ilişkin görüşleri. Kalem Eğitim ve İnsan Bilimleri Dergisi, 1(1), 189-226. https://doi.org/10.23863/kalem.2017.6

Özcan, M. (2011). Bilgi çağında öğretmen - eğitimi, nitelikleri ve gücü - bir reform önerisi. Ankara: Türk Eğitim Derneği (TED) İktisadi İşletmesi.

Pipere, A., Veisson, M., \& Salite, I. (2015). Developing research in teacher education for sustainability: Un DESD via the journal of teacher education for sustainability. Journal of Teacher Education for Sustainability, 17(2), 5-43. https://doi.org/10.1515/jtes-2015-0009

Plunkett, M. (2002). Impacting on teacher attitudes toward gifted students. In W. Vialle \& J. Geake (Eds.), The gifted enigma (pp. 240-249). Melbourne, VIC: Hawker Brownlow.

Pomortseva, N. P. (2014). Teaching gifted children in regular classroom in the USA. Proceedings of Social And Behavioral Sciences, 143, 147-151. https://doi.org/10.1016/j.sbspro.2014.07.377

Posnanski, T. (2002). Professional development programs for elementary science teachers: an analysis of teacher self-efficacy beliefs and a professional development model. Journal of Science Teacher Education, 13(2), 189-220. https://doi.org/10.1023/A:1016517100186 
Reid, E., \& Horvathova, B. (2016). Teacher training programs for gifted education with focus on sustainability. Journal of Teacher Education for Sustainability, 18(2), 66-74. https://doi.org/10.1515/jtes-2016-0015

Rogers, K. B. (2007). Lessons learned about educating the gifted and talented: A synthesis of research on educational practice. Gifted Child Quarterly, 51(4), 382-396. https://doi.org/10.1177/0016986207306324

Schultz, W., Dayan, P., \& Montague, P. R. (1997). A neural substrate of prediction and reward. Science, 275(5306), 1593-1599. https://doi.org/10.1126/science.275.5306.1593

Sterling, S. (2008). Sustainable education towards a deep learning response to unsustainability. Policy \& Practice. A Development Education Review, 6, Spring, 63-68. Retrieved February 15, 2018, from $\mathrm{http}: / / \mathrm{www}$. developmenteducationreview.com/issue6perspectives1

Strauss, A., \& Corbin, J. (1990). Basics of qualitative research: Grounded theory procedures and techniques. Newbury Park, CA: Sage.

Taylor, T., \& Milton, M. (2006). Preparation for teaching gifted students: An investigation into university courses in Australia. Australian Journal of Gifted Education, 15(1), 25-31.

Vialle, W., \& Quigley, S. (2002). Does the teacher of the gifted need to be gifted? Gifted and Talented International, 17(2), 85-90. https://doi.org/10.1080/15332276.2002.11672992

Yüksel, A., \& Avcı, S. (2011). Farklılaştırılmış oğretim stratejileri ile sosyal bilgiler dersinin işlenmesi. 1.Ulusal İlköğretim Kongresi Bildirisi. Retrieved $\quad$ February 15, 2018, https://www.pegem.net/Akademi/butunkongrebildiriler.aspx?id=310

Zygmunt, T. (2016). Language education for sustainable development. Discourse and Communication for Sustainable Education, 7(1), 112-124. https://doi.org/10.1515/dcse-2016-0008

\section{Copyrights}

Copyright for this article is retained by the author(s), with first publication rights granted to the journal.

This is an open-access article distributed under the terms and conditions of the Creative Commons Attribution license (http://creativecommons.org/licenses/by/4.0/). 